\title{
PATENTS AND THE SUCCESS OF VENTURE-CAPITAL BACKED STARTUPS: USING EXAMINER ASSIGNMENT TO ESTIMATE CAUSAL EFFECTS
}

\section{Patrick Gaulé}

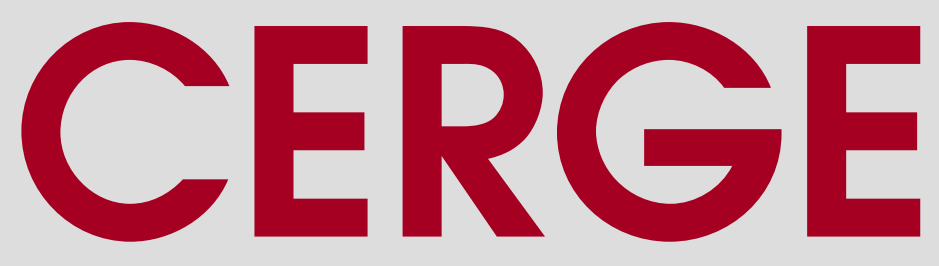

Charles University

Centerfor Economic Research and Graduate Education

Academy of Sciences of the Czech Republic

Economic Institute 


\section{Working Paper Series 546 (ISSN 1211-3298)}

\section{Patents and the Success of Venture-Capital Backed Startups: Using Examiner Assignment to Estimate Causal Effects}

Patrick Gaulé

CERGE-EI

Prague, July 2015 
ISBN 978-80-7343-352-9 (Univerzita Karlova v Praze, Centrum pro ekonomický výzkum a doktorské studium)

ISBN 978-80-7344-344-3 (Národohospodářský ústav AV ČR, v. v. i.) 


\title{
Patents and the Success of Venture-Capital Backed Startups: Using Examiner Assignment to Estimate Causal Effects
}

\author{
Patrick Gaulé*
}

July 27,2015

\begin{abstract}
I study how patents affect firm success (initial public offering or acquisition at a high price) in a sample of 2,191 U.S. startups applying for patent protection in the 24 months following their first round of venture capital funding. I observe both successful and unsuccessful patent applications and use a measure of patent examiner leniency as an instrument for getting patents. I find a positive effect of patents on firm success for life science firms but not for information technology firms.
\end{abstract}

Keywords: Patents, Entrepreneurship, Venture Capital, Patent Examiners, Acquisition, Initial Public Offering

JEL Classification: O34, G24, L26

\footnotetext{
${ }^{*}$ CERGE-EI is a joint workplace of Charles University in Prague and the Economics Institute of the Academy of Sciences of the Czech Republic, Politickych veznu 7, 11121 Prague, Czech Republic. Address: CERGE-EI, P.O. Box 882, Politických veznu 7, Prague 1, 111 21, Czech Republic; patrickgaule@gmail.com. The research contributes to the agenda Strategie AV21. I thank Ruchir Agarwal, Daniel Chen, Annamaria Conti, Michael Ewens, Christian Fons-Rosen, Ina Ganguli, Xavier Giroud, Stepan Jurajda, Francis Kramarz, Josh Lerner, Nikolas Mittag, Filip Pertold and Scott Stern for helpful discussions and advice. I benefited from comments of seminar and conference participants at CERGE-EI, Barcelona GSE Summer Forum and the SEARLE Eighth Annual Conference on Innovation Economics at Northwestern University. I am grateful to Paul Whitaker from the Academic Skills Center at CERGE-EI for careful editing. All errors are mine.
} 


\begin{abstract}
Abstrakt
Studuji, jak udělení patentu ovlivňuje úspěšnost firmy (primární emise akcií nebo akvizice firmy za vysokou cenu). Ve vzorku 2,191 startupu z USA, které si žádaly o patentovou ochranu v období 24 měsícu po prvním kole financování venture kapitálem, pozoruji úspěšné i neúspěšné patentové žádosti. Jako instrument pro udělení patentu využívám shovívavost patentových úředníku. Nacházím pozitivní efekt patentu na úspěšnost firem $\mathrm{v}$ odvětví life sciences, ale ne $\mathrm{v}$ př́padě firem $\mathrm{v}$ odvětví informačních technologií.
\end{abstract}




\section{Introduction}

Patents are often thought to be a key source of competitive advantage for entrepreneurial firms either by slowing or deterring competitor entry in product markets or by facilitating access to capital through a signalling function. However, it has proved difficult to establish empirically a direct causal link between patents and entrepreneurial firm success. If patents are milestones for entrepreneurial firms, one would clearly expect a correlation between patents and firm success. However, it is unclear that this correlation merely reflects the fact that more innovative firms tend to be more successful or whether it indicates that getting patents actually improves firms' outcomes.

In this paper, I use differences in leniency across patent examiners as a plausibly exogeneous source of variation in getting patents, and use this variation to investigate the causal effect of patents on the success of venture-backed firms. The main task of patent examiners - evaluating the novelty and non-obviousness of an application - necessarily involves judgement, and thus discretion. As initially suggested by Cockburn, Kortum \& Stern (2003), this can lead to considerable heterogeneity across patent examiners: there may be as many different patent offices as there are patent examiners. One type of patent examiner heterogeneity has been documented in recent work by Lemley \& Sampat (2012) and Frakes \& Wasserman (2014): more senior examiners cite less prior art and are more likely to grant patents. ${ }^{1}$

The empirical strategy employed in this paper is similar in spirit to the literature using exogeneous allocation of cases to judges or examiners to estimate the effect of court decisions or program receipt on a variety of outcomes (Kling 2006, Doyle 2007, Doyle 2008, Chang \& Schoar 2008, Maestas et al. 2015, Dobbie \& Song 2015, Galasso \& Schankerman 2015, and others). Closest to this paper, Sampat \& Williams (2015) use patent examiner heterogeneity in their study of patents and cumulative innovation. To my best knowledge, this is the first paper linking examiner exogeneity to venture-backed firms, and firm-level outcomes more generally.

My analysis is based on a sample of 2,191 U.S. entrepreneurial firms that file one or more patent applications between 2001 and 2006 and within 24 months of raising their first round of venture capital (VC) financing. I code entrepreneurial success as going through an initial public offering or being acquired for more than twice the amount of

\footnotetext{
${ }^{1}$ Besides variation within examiners, we might also expect variation across examiners in terms of how intensively they search for prior art or their receptiveness to arguments raised by applicants in the patent prosecution process.
} 
VC financing raised. Comparing firms that filed the same number of patents but were more or less successful in converting applications due to examiner assignment, I find a positive effect of patents on firm success for life science firms but not for information technology firms. Within the sample of life science firms, the effect of having any patent is substantially larger than the effect of having a patent. The differential results between information technology and life science are remarkably consistent with cross-industry differences in the effectiveness of patents as means of appropriating returns from $R \& D$, as reported in surveys of R\&D managers in large firms (Mansfield 1986, Levin et al. 1987, Cohen et al. 2000) and high technology entrepreneurs (Graham et al. 2008).

This paper contributes to the literature on the determinants of success for venture capital-backed firms and entrepreneurial firms more generally. A large branch of this literature investigate whether venture capitalists in particular have a causal effect on firms exits (see, among others, Hellman \& Puri 2000, Puri \& Zarutskie 2012, Bernstein et al. 2015). Other studies consider the role of social networks (Hochberg et al. 2007), the characteristics of founding teams (Beckman et al. 2007), the regional supply of young workers (Ouimet \& Zarutskie 2014), or investment cycles (Nanda \& Rhodes-Kopf 2013). Closer to this paper, Mann and Sager (2007) and Cockburn \& MacGarvie (2009) find that software venture-capital backed firms that have patents are more likely to have an initial public offering but their results are descriptive, rather than causal. Hsu and Ziedonis (2013) find that that increases in patent stocks lead to increases in venture capitalists' estimates of company value for a sample of semiconductor startups. The present paper provides causal evidence on the role of legal protection to invention in the form of patents as a key determinant of entrepreneurial success in some industries.

The rest of this paper proceeds as follows. Section 2 provides background information on patent prosecution and the assignment of patents to examiners at the United States Patent and Trademark Office (USPTO). Section 3 and 4 present the data and empirical strategy respectively. The results are in section 5 and section 6 concludes.

\section{Examiners and patent prosecution at the USPTO}

Upon arriving at the U.S. Patent and Trademark Office, patent applications are sorted by a dedicated classification office and allocated to "art units" specialized in given technology 
areas (Cockburn, Kortum \& Stern 2003). ${ }^{2}$ Within an art unit, a Supervisory Patent Examiner assigns patents to individual examiners (ibid.). Details on how applications are allocated within the art unit are not made public by the U.S. patent office but previous studies (Cockburn, Kortum \& Stern 2003, Lemley \& Sampat 2012) report the results of interviews regarding allocation of patents to examiners. A common practice is for supervisory examiners to assign patents based upon the last digit of the application serial number, which itself is assigned sequentially by a central office (Lemley \& Sampat 2012). A minority of supervisory examiners gave the oldest unassigned application to an examiner when that examiner finished examining a prior application (ibid.). ${ }^{3}$

Whether assignment to examiners within art units is as good as random is an open question but it seems plausible. Lemley \& Sampat (2012) conclude from interviews that there is no purposeful allocation of applications to examiners. As noted by Sampat \& Williams (2015), there is limited scope for purposeful allocation within the art unit given that the supervisory examiner has limited information on the likely patentability of an application (short of doing a substantive evaluation himself/herself). To the extent that it would be feasible for the supervisory examiner to recognize 'easy' applications, attempts to assign such patents disproportionately across examiners would be resisted internally as this would be perceived as un unfair distribution of the workload across examiners. Previous studies report no difference in observables across patents assigned to lenient examiners (Sampat \& Williams 2015) and more senior examiners (Lemley \& Sampat 2012) respectively.

Once a patent application is assigned to an examiner, (s)he will typically have continuing responsibility for the case. The examiner is tasked with searching the prior art to determine whether the application and its claims meet the requirement of novelty and non-obviousness. ${ }^{4}$ Based upon his/her assessment the examiner issues a "first office action" in which the application is either accepted or rejected. Less than $15 \%$ of first office actions are acceptances (Lemley \& Sampat 2010). However, if the application is rejected, the applicant can argue against the examiner's objections (laid down in the rejection letter) or choose to narrow the claims. A back and forth process between the applicant and the examiner ensues. Eventually, around $56 \%$ of applications are granted

\footnotetext{
${ }^{2}$ This section draws heavily upon Cockburn, Kortum \& Stern (2003), Lemley \& Sampat (2008, 2010 and 2012)

${ }^{3}$ Cockburn, Kortum \& Stern (2003) report that in some mechanical art units an examiner would specialize in a narrow technological area and deal with all incoming patents in that area. However, this does not appear to be a general pattern.

${ }^{4}$ The examiner also checks a number of legal requirements including whether the application covers a patentable subject matter.
} 
(Carley, Hegde \& Marco 2015). ${ }^{5}$ While the patent prosecution process is heavily codified, examiners nonetheless have considerable discretion. However, examiner discretion is counterbalanced by the applicants' ability to appeal UPSTO decisions as well as the possibility for granted patents to be invalidated by courts.

\section{Data}

I combined data from multiple sources to build the analysis data set. Data on venturebacked companies, including firm names and information on founding rounds, came from Thomson Reuters' VentureXpert. VentureXpert is one of the main sources of information on venture capital and has been widely used in entrepreneurship research. From VentureXpert, I got the names of 17,089 U.S. companies who had their venture capital round between 1999 and 2006, according to VentureXpert. After excluding firms that are classified as "Non-High Technology" (5,333 or 31.2\%), I had 11,756 companies.

Regarding patent application data, I collected data both from USPTO patent assignments record and from USPTO Patent Application Information Retrieval (PAIR). For assignments, I collected patent assignment data from from the USPTO website. ${ }^{6}$ I focused on application numbers $9,800,000$ to $11,800,000$ which roughly correspond to patent applications filed between 2001 and 2007. ${ }^{7}$ For information on which patent applications are assigned to which examiners, I collected data from the USPTO PAIR system distributed through Google. ${ }^{8}$ I collected bibliographic patent application information, including patent examiner name and grant status for patent applications ranging from application numbers $9,800,000$ to $11,800,000$.

The matching procedure between companies and patent application assignment records is as follows. First, I selected assignments that are made no earlier than 7 days before the filing date, and no later than 90 days after the filing date. ${ }^{9}$ Second, I used a name stan-

\footnotetext{
${ }^{5}$ This figure excludes continuation procedures to create related applications.

${ }^{6} \mathrm{http}: / /$ assignment.uspto.gov/

${ }^{7}$ Prior to November 2000, the USPTO did not publish patent applications, though patent offices in most other countries published applications 18 months after the filing date. The American Inventors Protection Act (AIPA) required inventors applying for patents at USPTO on or after November 29, 2000 to publish their applications 18 months after the filing date. There is an opt-out provision for applications that will not be filed outside the U.S. but this provision has been used in less than $10 \%$ of applications (Graham \& Hegde 2015).)

${ }^{8}$ http://www.google.com/googlebooks/uspto-patents-pair.html

${ }^{9}$ The assignment data include both the initial assignment (if any) from the inventors to an assignee and subsequent re-assignments. The initial assignment date need not correspond to the filing date and while it is common for the initial assignment date to be the same as the file, it is also common for the
} 
dardization procedure to standardize firm names in the assignment and in the venture capital data. The procedure followed closely that of the NBER patent data project. ${ }^{10}$ Third, I matched assignment records to firm names if the standardized names match exactly. Since this may be failing to match firms names whose name has been misspelled, I also considered the set of possible matches that have a Levenshtein distance (a standard measure of distance between strings) of one. In this set, I inspected the matches manually to determine whether the match is correct. Fourth, I kept patent applications that were filed in the 24 months following the first venture capital round. I focus on patent applications filed relatively shortly after the first round since I expect these to matter more for firm outcomes.

After the matching procedure is complete, I had 7,978 patents corresponding to 2,274 distinct firms. For each of these patent applications, I used patent application bibliometric data from USPTO PAIR to find the set of applications that were filed in the same year and allocated to the same examiner, as well as the set of applications that were filed in the same year and allocated to the same art unit. On average, the set of applications filed in the same year and allocated to the same examiner had 41 elements. To avoid error in measuring examiner leniency when the set of applications is small, I dropped 500 applications for which the set of applications filed in the same year and allocated to the same examiner has 5 elements or less. ${ }^{11}$

The final analysis sample has 2,191 firms. The majority firms in my sample are in IT $(76 \%)$ with the rest (24\%) in Medical/Health/Life science (hereafter: "Life Science"). This industry classification corresponds to "company industry class" in VentureXpert. The firms received their first VC round between 1999 and 2006, with a mean first round investment around 8.6 million USD.

[Insert table 2 about here]

About $8 \%$ of firms in my sample go public while $42 \%$ are acquired by, or merged with, another company and $40 \%$ of firms were still active as of $2014 .^{12}$ Acquisitions by other companies clearly cover very heterogeneous scenarios, ranging from exits that are very lucrative for the entrepreneur and his/her VC backers to essentially firesales. To better understand and classify exits, I manually collected acquisition details through assignment date to be after or just before the filing date.

${ }^{10} \mathrm{http}$ ///sites.google.com/site/patentdataproject/Home/posts/namestandardizationroutinesuploaded

${ }^{11}$ Including these applications does not weaken my results.

${ }^{12}$ If a firm has an IPO and is subsequently acquired, it is treated as an IPO 
press releases and business press articles for the 917 firms in the analysis sample that were acquired by other firms. This yielded the acquisition price for 359 firms while the financial terms could not be found for the remaining 558 firms, typically because the parties chose to not disclose terms. ${ }^{13}$ Then following Ewens \& Marx (2014), I classified an acquisition as 'High acquisition' if the acquisition price is more than $200 \%$ the total amount of venture capital raised by the firm. ${ }^{14}$ Finally, I defined entrepreneurial success as firms that either went public or were the subject of 'high acquisitions'. Around 19\% of firms are deemed successful according to that coding.

An average firm files 3.3 applications in the 24 months following their first VC round, of which 2.1 are granted. ${ }^{15}$ The distribution of applications is skewed to the right with $43 \%$ of firms filing just one application.

Considering the individual patent applications that are matched to firms, an individual patent application has a $60 \%$ chance of being granted. The examiners of patents in sample have each dealt on average with 41 other applications filed in the same year (standard deviation 28.8). ${ }^{16}$ The difference between the examiner grant rate and unit grant rate has mean 0 and standard deviation 0.14 .

\section{Empirical strategy}

A natural starting point to understand the effect of patent on entrepreneurial firms is to compare firms that have patents to those that do not. A problem with that approach is that firms without patents include both firms that did not generate patentable inventions, firms that had patentable inventions but chose not to apply for protection and firms that applied for patent but did not get patent protection. To derive meaningful inference about the effect of patents, it is clearly important to distinguish among these three groups of control firms. The firms that do not generate inventions are not an appealing

\footnotetext{
${ }^{13}$ Under some conditions, disclosure of financial terms is mandatory but is otherwise at the discretion of the parties. Non-disclosure may occur both when the price paid was high (and the acquiring the firm does not want to be perceived as having overpaid) or when the price paid was low (and the entrepreneur or venture capitalist does not want to reveal losses made).

${ }^{14} \mathrm{My}$ results are robust to using $150 \%$ or $250 \%$ instead.

${ }^{15}$ Applications are observed with some error. For instance for firms that had their first round in 2006 , I do not observe applications in 2008 even though that would be within 24 months of the first VC round. Conversely, I do not see applications filed in 2000 for firms that had their first round in 1999 or 2000.

${ }^{16}$ Applications where the number of applications assigned to same examiner in a given year is 5 or less have already been excluded from the sample as examiner leniency is imprecisely observed in those cases. Including these applications does not weaken the results.
} 
control group as the difference with patenting firms mechanically conflates the effect of the patent with the effect of the invention itself. Firms that had patentable inventions but chose not to apply for patent protection are a more interesting control group but it is empirically difficult to distinguish them from firms that do not generate inventions. Moreover, the decision to patent is clearly a choice of the firm that is made considering the returns to different appropriations strategies (patenting versus secrecy).

Another possible control group is firms that apply for patent protection but do not get it. The key empirical challenge here is that the USPTO does not randomly grant patents. Instead, the USPTO conducts a detailed investigation to determine the patentability of inventions. This makes it intrinsically difficult to separate the causal effect of patents from differences in the firms that submit these inventions as patent applications. While the patent office is not evaluating the quality of a technology as such, it is searching for prior art and evaluating novelty and non-obviousness. A patent applicant that has a radical and cutting edge invention will presumably find it easier to convince the patent office that the claimed invention meets the non-obviousness requirement. Alternatively, a better firm may hire more skilled patent attorneys that navigate the patent prosecution more effectively.

The empirical strategy in this paper is based on comparing firms that file the same number of patent applications (in a 24 month time window from receiving venture capital) but were more or less successful in converting their applications into granted patents. I aim to identify the causal effects of patents on firm success by using differences across firms in examiner leniency. Intuitively, some firms 'get lucky' by drawing more lenient patent examiners and I use variation in patents granted that are induced by the assignment to such examiners. I use a time-varying measure of examiner leniency, as it has been found that examiners tend to get more lenient as they are promoted and their case loads increase (Frakes \& Wasserman 2014). ${ }^{17}$ However, the variation in examiner leniency comes not only from the variation within examiners but also from variation across examiners, as different examiners may be different in the effectiveness of their search for prior art, or in their standard for for assessing non-obviousness.

Let us consider a patent application $j$, filed in year $t$, allocated to art unit $u$ and assigned to patent examiner $k$. I define the following quantities:

$$
E_{j t}=\frac{\text { grants }_{k t}-\mathbf{1}\left(\text { grant }_{j}=1\right)}{\text { applications }_{k t}-1}
$$

\footnotetext{
${ }^{17} \mathrm{~A}$ more practical reason for using time-varying leniency is that I do not observe leniency for patents applied before 2001 .
} 


$$
U_{j t}=\frac{\text { grants }_{u t}-\mathbf{1}\left(\text { grant }_{j}=1\right)}{\text { applications }_{u t}-1}
$$

where grants $_{k t}$ is the number of patents filed in year $t$ and granted by examiner $k$, grant $_{u t}$ is the number of patents filed in year $t$ and granted by art unit $u$, application apt is the number of applications filed in year $t$ and assigned to examiner $k$, application $_{u t}$ is the number of applications filed in year $t$ and allocated to art unit $u$. $E_{j t}$ is thus simply the share of applications that have the same application year as $j$ that were granted by the examiner dealing with that application, excluding the focal patent. Similarly, $U_{j t}$ is the share of applications that have the same application year as $j$ that were granted by art unit $u$, excluding the focal patent. The difference $E_{j t}-U_{j t}$ is thus the difference between the leniency of an examiner and the average leniency facing an applicant filing in year $t$ in the technological area corresponding to art unit $u$.

For firms that file a single patent application, the difference $E_{j t}-U_{j t}$ between the leniency of an examiner and the average leniency of the art unit can be used as an instrument for whether that application is granted. The resulting empirical setup would track closely prior studies on judges and examiners that uses a leave-one-out measure of leniency (see in particular Dobbie \& Song 2014). ${ }^{18}$ However, firms may apply for multiple patents and thus get 'treated' by more or less stringent examiners multiple times. I deal with this by averaging the difference $E_{j t}-U_{j t}$ across the patents applied for by firm $i$, leading to the instrument:

$$
Z_{i}=\frac{1}{n} \sum_{j}\left(E_{j t}-U_{j t}\right)
$$

One concern with averaging examiner leniency across applications is that firms may react to getting a stringent examiner on the first application by filing more applications. In my sample by construction all applications are made in a two year window (after the first VC round), which limits the scope for such behavior since the outcome of the examination process and/or the identity of the examiner would not be known within the first year of filing. Empirically, I do not observe a correlation between examiner leniency in the first application and the number of subsequent applications filed (cf table 3 column $1)$.

I use the instrument $Z_{i}$ for the number of patents the firm gets in a standard two

\footnotetext{
${ }^{18}$ The alternative to using a leave-one-out measure of leniency is to estimate sets of judge/examiner fixed effects (see e.g. Angrist, Imbens \& Krueger 1999).
} 
stages least squares framework.

$$
\begin{gathered}
\text { Patents }_{i}=\beta_{0}+\beta_{1} Z_{i}+\beta_{2} X_{i}+\epsilon_{i} \\
Y_{i}=\delta_{0}+\delta_{1} \text { Patent }_{i}+\delta_{2} X_{i}+u_{i}
\end{gathered}
$$

Where $Y_{i}$ is a firm outcome, such as entrepreneurial success and $X_{i}$ is a set of controls. Following prior literature (Kling 2006, Chang \& Schoar 2008, Doyle 2007, Doyle 2008, Ayzer \& Doyle 2013, Maestas et al. 2013, Sampat \& Williams 2015, Dobbie \& Song 2015), I do not adjusted the standard errors to account for the fact that examiner leniency is estimated.

The set of controls $X_{i}$ includes two types of fixed effects. The first are fixed effects for the number of applications filed by the firm, as I want to compare firms that filed the same number of applications. The second are technology sector by first round year fixed effects. $^{19}$ I control for these for efficiency reasons as technology sector and the year of the first round are powerful determinants of firm outcomes. I obtain very similar point estimates, but somewhat larger standard errors when I omit these controls.

The two-stage least squares estimates will measure the local average treatment effect of patents for firms whose patent outcomes were changed by examiner assignment under two conditions: (1) examiner assignment is associated with patent protection and (2) examiner assignment is related to firm outcomes only through the granting of patents.

The first assumption is empirically testable. In table 2, I show a regression of granted patents on examiner leniency, i.e. the first stage of the two-stage least squares estimation. A one standard deviation in the leniency of the examiners a firm was assigned increases the number of patents granted by 0.219. Differences across examiners appear to be a driver of differences in the likelihood that a patent will be issued, even for a given technology type and year of application. Correspondingly, the instrument explains a large part of the variation in granted patents, which is reflected by the first stage $\mathrm{F}$ statistic of over 130, well in excess of the critical values for weak instruments tests.

\section{[Insert table 2 about here]}

\footnotetext{
${ }^{19}$ For the purpose of constructing these fixed effects, I used a finer grained definition of the technological sector, based upon VentureXpert classification. Specifically, the technological sector is one of the following: biotechnology, communications, computer hardware, computer software, internet specific, medical/health and semiconductor. Note that the art unit division at the USPTO corresponds to much finer grained classifications of the technological sector.
} 
The second identifying assumption is that examiner assignment is related to firm outcomes only through the granting of patents. This would be violated if examiner assignment was correlated with observable or unobservable determinants of firm outcomes (such as firm quality). While the validity of the instrument cannot be tested directly, I also run two types of regressions to partially assess the validity of the examiner instrument. First, I regress predetermined characteristics of the firm on the examiner instrument. As reported in table 4, I find no significant association between the leniency of the examiner and the amount raised in the first round, the number of investors in the first round, or time between firm founding and time of the first VC round.

[Insert table 4 about here]

A possible lingering concern is that better firms may find ways to get their patents assigned to more lenient examiners (perhaps by employing more skilled intellectual property counsel). To partially address this concern, I conduct the following falsification exercise. If better firms were consistently able to select more lenient examiners, we would expect firms that manage to get a lenient examiner in their first applications to also get a lenient examiner in subsequent applications. In the presence of such selection, we should observe a positive correlation between the leniency of the examiner for the first application of the firm and the leniency of the examiner in subsequent applications. It turns out there is no such correlation empirically (see table 3$).^{20}$

[Insert table 3 about here]

\section{Results}

The main results are shown in table 5. The outcome variable is firm success which is defined as having an IPO or being acquired for more than twice the amount raised from venture capitalists. ${ }^{21}$ The variable of interest is the number of applications by the firm that were granted (among the set of applications filed by the firm in the first 24 months since receiving venture capital funding). All specifications include fixed effects for the number of applications. The coefficient on patents can thus be interpreted as the effect

\footnotetext{
${ }^{20}$ For the purpose of this exercise, I drop applications originating from the same company that have the same filing date.

${ }^{21}$ The coding of high acquisition follows Ewens \& Marx (2014). I explore the sensitivity of results to alternative thresholds later in this section.
} 
of a (possibly additional) granted patent, holding the number of applications constant. I also control for technological sector by first venture capital round year fixed effects. All regressions are estimated with two-stage least squares. The first column presents the result for the full sample. Columns two and three display results for the IT subsample and the Life Science subsample respectively.

[Insert table 5 about here]

In the full sample, the point estimate of the effect of patents is positive but not significant. This is the case for the IT subsample as well. However, the confidence intervals are relatively large in both cases so that an economically meaningful effect of patents cannot be ruled out. In the Life Science subsample, however, the point estimate is positive and significant at $5 \%$. That point estimate, while imprecisely estimated, corresponds to an economically large effect, with a patent improving the likelihood of firm success by around 15\% (compared to a baseline of 29\%).

[Insert table 6 about here]

In table 6 , I look at the effect of having any patent on firm success. The endogeneous variable is now an indicator variable for having any patent instead of the number of patents. The empirical setup is otherwise the same as before. In particular, I control for fixed effects for the number of patents applied, hence comparing firms which filed the same number of applications. The effect of any patent is positive, but not significant, in the whole sample and in the IT subsample. In the life science sample, the effect is positive and significant at the $5 \%$ confidence level. Interestingly, the point estimate is more than double compared to the regressions with all patents as endogeneous variables (0.33 versus 0.15$)$. Thus, it seems that the first patent is considerably more important than subsequent ones.

[Insert table 7 about here]

A possible concern with the previous sets of regressions is that more lenient examiners may affect firm success not only by granting patents but also by granting them more quickly or with a broader scope. In that case, it is interesting to look at the reduced form regressions of mean examiner leniency on firm success. These regressions relate firm 
success to mean examiner leniency but remain agnostic as to the exact channel (speed of examination, scope of the granted claims or just whether the patent is granted or not) through which the effect operates. Reduced form estimates of the impact of mean examiner leniency on firm success are presented in table 7 . The point estimates for the whole sample and for IT firms are positive but not significant. The point estimate for the Life Science subsample is positive and significant at the $5 \%$ confidence level. In this industry, a firm that was one standard deviation luckier than average in the examiner(s) it got has a $3.6 \%$ higher chance of being successful. The magnitude of the effect is lower than that of the effect of getting patents. This makes sense since only some firms that get assigned a lenient examiner actually experience different patent outcomes than they would with more stringent examiners. ${ }^{22}$

\section{Conclusion}

This paper studies the impact of patents on entrepreneurial firms using a sample of U.S. venture-backed firms matched to their patent applications in a relatively short time window after the first round (24 months). I compare firms that filed the same number of patent applications at the USPTO, but had more or less success in converting these applications into granted patents due to differences in leniency across the patent examiners they got. This approach aims to identify the local average treatment effect of patents for firms whose patenting outcomes were altered by examiner assignment. Conditional on the technology type and year of application, firms have little influence on the examiner their applications are assigned to. In fact, I show that in my sample firms that get a lenient examiner in their first application are no more or less likely to get a lenient examiner in subsequent applications. The assignment of patent examiners to applications appears to be exogeneous, and hence it constitutes a promising empirical strategy to understand the effect of patents on firms.

I find that patents increase the likelihood of firm success for firms in the life science sector. However, I find no significant effect of patents in the information technology sector. Interpreting these results involves going back to the basic question of why having patents should matter to entrepreneurial firms. Patent protection is intended to provide a means for firms to appropriate returns to invention. The empirical literature on appropriability based on surveys of R\&D managers in firms (see Mansfield 1986, Levin et al. 1987,

\footnotetext{
${ }^{22}$ The instrumental regressions identify the local average treatment effect of patents for firms whose patents were altered by examiner assignment.
} 
Cohen et al. 2000; and the literature review of Cohen (2010)) emphasizes cross-industry differences in the usefulness of patents as a means of appropriating returns to innovation. Specifically, it is only in certain industries - pharmaceuticals, medical devices and to a less extent chemicals - that R\&D managers report patents to be very effective for appropriability. In a more recent survey of high technology entrepreneurs, Graham et al. (2009) report that patents are perceived as the most important appropriability strategy for biotechnology firms. ${ }^{23}$ My results - that patents have significant effects only for firms in life science map quite well into these sectoral differences in perceived appropriability. An intuitive interpretation for my findings is that patents help VC-backed firms in the life science sectors succeed by facilitating the appropriation of returns to invention.

Other mechanisms could be at play. For instance, patents may serve a signalling or certification function to investors and facilitate access to capital (Conti et al. 2013a, Conti et al. 2013b, Haeussler et al. 2014). To the extent that entrepreneurial firms are constrained by access to capital, easier access to capital enabled by patents could then spur firm growth and success. It is unclear why this would happen only in the life science industry though.

Further research may seek to address various limitations of this study. First, the dependent variables (firm success) is imperfectly observed. Second, getting the first round of venture capital is itself an intermediate outcome that entrepreneurial firms typical strive to achieve. Instead of considering the effect of patents for firms that have raised a first round of venture capital funding, one could look at the effect of patents on the likelihood of receiving the first round of venture capital funding. Third, with venture capital data not much is known about the firms besides the timing and size of the investments. Linking examiner heterogeneity to other firm data may address these limitations and shed more light on whether and how patents matter for entrepreneurial firms.

\section{References}

Angrist, J. D., Imbens, G., \& Krueger, A. B. (1999). Jackknife Instrumental Variables Estimation. Journal of Applied Econometrics, 14(1), 57-67.

Beckman, C. M., Burton, M. D., \& O'Reilly, C. (2007). Early teams: The impact

\footnotetext{
${ }^{23}$ Patents are also reported to be important in medical devices and IT hardware.
} 
of team demography on VC financing and going public. Journal of Business Venturing, $22(2), 147-173$.

Bernstein, S., Giroud, X., \& Townsend, R. (2015). The Impact of Venture Capital Monitoring. Journal of Finance (forthcoming)

Carley, M., Hegde, S. \& Marco, A.C. (2014). What is the Probability of Receiving a U.S. Patent? 17 Yale Journal of Law and Technology 203

Chang, T., \& Schoar, A. (2008). Judge Specific Differences in Chapter 11 and Firm Outcomes. Unpublished Working Paper.

Cockburn, I. M., Kortum, S., \& Stern, S. (2002). Are all patent examiners equal? The impact of examiner characteristics. NBER Working Paper No 8980. National Bureau of Economic Research.

Cockburn, I. M., \& MacGarvie, M. J. (2009). Patents, Thickets and the Financing of Early-Stage Firms: Evidence from the Software Industry. Journal of Economics \& Management Strategy, 18(3), 729-773.

Cohen, W. M., Nelson, R. R., \& Walsh, J. P. (2000). Protecting their intellectual assets: Appropriability conditions and why US manufacturing firms patent (or not). NBER Working Paper No 8980. National Bureau of Economic Research.

Cohen, W. M. (2010). Fifty years of empirical studies of innovative activity and performance. Handbook of the Economics of Innovation, 1, 129-213.

Conti, A., Thursby, M., \& Rothaermel, F. T. (2013a). Show Me the Right Stuff: Signals for High-Tech Startups. Journal of Economics \& Management Strategy, 22(2), 341-364.

Conti, A., Thursby, J., \& Thursby, M. (2013b). Patents as Signals for Startup Financing. Journal of Industrial Economics, 61(3), 592-622.

Dobbie, W., \& Song, J. (2015). Debt Relief and Debtor Outcomes: Measuring the Effects of Consumer Bankruptcy Protection. American Economic Review, 105(3), 12721311.

Doyle, J. J. (2007). Child protection and child outcomes: Measuring the effects of foster care. American Economic Review, 97(5), 1583-1610.

Doyle, J. J. (2008). Child protection and adult crime: Using investigator assignment 
to estimate causal effects of foster care. Journal of Political Economy, 116(4), 746-770.

Ewens, M., Marx, M. (2014). Executive Replacement in Venture Capital-Backed Startups. Mimeo, MIT and California Institute of Technology. Working Paper.

Frakes, M. D., \& Wasserman, M. F. (2014). Is the Time Allocated to Review Patent Applications Inducing Examiners to Grant Invalid Patents? NBER Working Paper No 20337. National Bureau of Economic Research.

Galasso, A., \& Schankerman, M. (2015). Patents and Cumulative Innovation: Causal Evidence from the Courts. Quarterly Journal of Economics, 130(1), 317-369.

Graham, S. J. \& Hedge, D. (2015) Disclosing patents' secrets. Science, 347(6219):236237

Graham, S. J., Merges, R. P., Samuelson, P., \& Sichelman, T. M. (2009). High technology entrepreneurs and the patent system: Results of the 2008 Berkeley patent survey. Berkeley Technology Law Journal, 24(4), 255-327.

Haeussler, C., Harhoff, D., \& Mueller, E. (2014). How patenting informs VC investors - the case of biotechnology. Research Policy, 43(8):1286-1298.

Hellman, T., \& Puri, M. (2000). The interaction between product market and financing strategy: The role of venture capital. Review of Financial Studies, 13(4), 959-984.

Hochberg, Y. V., Ljungqvist, A., \& Lu, Y. (2007). Whom you know matters: Venture capital networks and investment performance. Journal of Finance, 62(1), 251-301.

Hsu, D. H., \& Ziedonis, R. H. (2013). Resources as dual sources of advantage: Implications for valuing entrepreneurial-firm patents. Strategic Management Journal, 34(7), 761-781.

Kling, J.R. (2006) Incarceration Length, Employment and Earnings. American Economic Review, 96(3):863-876

Lemley, M., \& Sampat, B. (2008). Is the patent office a rubber stamp? Emory Law Journal, 58, 181-203

Lemley, M., \& Sampat, B. (2010). Examining patent examination. Stanford Technology Law Review, 2010, 2

Lemley, M., \& Sampat, B. (2012). Examiner characteristics and patent office out- 
comes. Review of Economics and Statistics, 94(3):817-827

Levin, R. C., Klevorick, A. K., Nelson, R. R., Winter, S. G., Gilbert, R., \& Griliches, Z. (1987). Appropriating the returns from industrial research and development. Brookings Papers on Economic Activity, 783-831.

Maestas, N., Mullen, K., \& Strand, A. (2013). Does disability insurance receipt discourage work? Using examiner assignment to estimate causal effects of SSDI receipt. American Economic Review, 103(5), 1797-1829

Mansfield, E. (1986). Patents and innovation: an empirical study. Management Science, 32(2), 173-181.

Mann, R. J., \& Sager, T. W. (2007). Patents, venture capital, and software start-ups. Research Policy, 36(2), 193-208.

Nanda, R., \& Rhodes-Kropf, M. (2013). Investment cycles and startup innovation. Journal of Financial Economics, 110(2), 403-418.

Ouimet, P., \& Zarutskie, R. (2014). Who works for startups? The relation between firm age, employee age, and growth. Journal of Financial Economics, 112(3), 386-407.

Puri, M., \& Zarutskie, R. (2012). On the life cycle dynamics of venture-capital-and non-venture-capital-financed firms. Journal of Finance, 67(6), 2247-2293.

Sampat, B., \& Williams, H. (2015). How do patents affect follow-on innovation? Evidence from the human genome. Working Paper. 


\section{Tables}

Table 1: Descriptive statistics

\begin{tabular}{lrr}
\hline \hline Panel A: Industry & No of companies & As fraction \\
Information Technology & 1,660 & 0.76 \\
Life Science $\left(^{*}\right)$ & 531 & 0.24 \\
& & \\
Panel B: Exit type & No of companies & As fraction \\
Success (Went Public or High acquisition) & 418 & 19.1 \\
Went Public & 186 & 0.08 \\
High acquisition & 232 & 0.11 \\
& & \\
Panel C: Financing variables & Mean & S.D. \\
& & \\
Year of first round & 2002 & 2.2 \\
First round amount (million USD) & 8.56 & 19.4 \\
First round number of investors & 2.63 & 1.67 \\
Time from founding to first round (years) & 2.97 & 6.17 \\
& & \\
Panel D: Patent variables at patent level & Mean & S.D. \\
Granted & & \\
Difference between examiner & 0.60 & 0.26 \\
grant rate and unit grant rate & 0.0 & 0.14 \\
Nr of applications assigned & & \\
to same examiner in given year (**) & 41.0 & 28.8 \\
Panel E: Patent variables at firm level & & \\
Patent applications & 3.3 & 4.6 \\
Granted patents & & \\
\hline \hline
\end{tabular}

Notes: (*) The industry classification is based on VentureXpert "Company industry class". I relabel "Medical/Health/Life Science" as "Life Science" for conciseness.(**) Applications where the number of applications assigned to the same examiner in a given year is 5 or less are excluded from the sample as examiner leniency is imprecisely observed in those cases. 
Table 2: First stage of the instrumental variable regressions

(1)

Patents

\begin{tabular}{lc} 
& Patents \\
\hline Mean examiner leniency & $0.217^{* * *}$ \\
(normalized) & $(0.019)$ \\
\hline Observations & 2191
\end{tabular}

Sector by 1st round year FE Yes

Nr of applications FE Yes

F-statistic 132

Mean of dependent variable $\quad 2.14$

R2 0.97

Notes: Robust standard errors in parentheses ${ }^{*} p<0.1,{ }^{* *} p<0.05,{ }^{* * *} p<0.01$. The lower number of observations in columns 2 and 3 are due to missing values for round amounts and age of founding respectively.

Table 3: Does examiner leniency in the first application predict subsequent applications or examiner leniency in subsequent applications?

\begin{tabular}{lcc}
\hline \hline & $\begin{array}{c}(1) \\
\text { Nr of subsequent } \\
\text { applications }\end{array}$ & $\begin{array}{c}(2) \\
\text { Examiner leniency } \\
\text { in subsequent applications }\end{array}$ \\
\hline Examiner leniency & -0.086 & 0.000 \\
in first application & $(0.162)$ & $(0.005)$ \\
(normalized) & & 991 \\
\hline Observations & 2191 & Yes \\
Technological sector by year FE & Yes & -0.00 \\
Mean of dependent variable & 2.30 & \\
\hline \hline
\end{tabular}

Notes: Robust standard errors in parentheses ${ }^{*} p<0.1,{ }^{* *} p<0.05,{ }^{* * *} p<0.01$.

Subsequent patent applications up until 24 months from the first venture capital round.

Firms that apply once do not appear in the second column, hence the lower number of observations.

Table 4: Instrument and first round characteristics

\begin{tabular}{lccc}
\hline \hline & $\begin{array}{c}(1) \\
\text { Nr investors }\end{array}$ & $\begin{array}{c}(2) \\
\text { Round amount }(\log )\end{array}$ & $\begin{array}{c}(3) \\
\text { Time since founding }\end{array}$ \\
\hline Mean examiner leniency & 0.001 & -0.008 & 0.036 \\
(normalized) & $(0.032)$ & $(0.027)$ & $(0.114)$ \\
\hline Observations & 2191 & 2050 & 1954 \\
Sector by 1st round year FE & Yes & Yes & Yes \\
Nr of applications FE & Yes & Yes & Yes \\
Mean of dependent variable & 2.63 & 8.36 & 2.97 \\
R2 & 0.06 & 0.10 & 0.10 \\
\hline \hline \multicolumn{4}{c}{ Notes: Robust standard errors in parentheses $* p<0.1,{ }^{* *} p<0.05,{ }^{* * *} p<0.01$. The } \\
number of observations is slightly lower in columns 2 and 3 due to missing values for first \\
round amount and year of founding, respectively
\end{tabular}




\begin{tabular}{lccc}
\hline \hline & $\begin{array}{c}\text { All } \\
(1)\end{array}$ & $\begin{array}{c}\text { IT only } \\
(2)\end{array}$ & $\begin{array}{c}\text { Life Science } \\
\text { Firm success }\end{array}$ \\
\hline Patents & \multicolumn{3}{c}{$0.149^{* *}$} \\
(instrumented) & 0.048 & 0.017 & $0.140 .076)$ \\
\hline Observations & $(0.037)$ & $(0.043)$ & $(0.071$ \\
Sector by 1st round year FE & Yes & 1660 & 531 \\
Nr of applications FE & Yes & Yes & Yes \\
Mean of dependent variable & 0.19 & 0.16 & 0.29 \\
First stage F statistic & 132 & 97 & 35 \\
\hline \hline
\end{tabular}

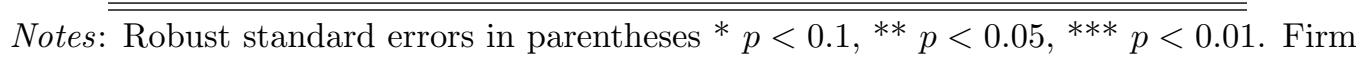
success is defined as having an IPO or being acquired at a high price (more than twice the amount raised from venture capitalists). All regressions are estimated with two-stage least squares.

Table 6: Any patent and firm success

\begin{tabular}{lccc}
\hline \hline & $\begin{array}{c}\text { All } \\
(1)\end{array}$ & $\begin{array}{c}\text { IT only } \\
(2)\end{array}$ & $\begin{array}{c}\text { Life science } \\
\text { Firm success }\end{array}$ \\
\hline Any patent & \multicolumn{3}{c}{$(3)$} \\
(instrumented) & 0.093 & 0.032 & $0.331^{* *}$ \\
\hline Observations & $(0.071)$ & $(0.078)$ & $(0.165)$ \\
Sector by 1st round year FE & 2191 & 1660 & 531 \\
Nr of applications FE & Yes & Yes & Yes \\
Mean of dependent variable & 0.19 & Yes & Yes \\
First stage F statistic & 133 & 101 & 0.29 \\
\hline \hline
\end{tabular}

Notes: Robust standard errors in parentheses ${ }^{*} p<0.1,{ }^{* *} p<0.05,{ }^{* * *} p<0.01$. Firm success is defined as having an IPO or being acquired at a high price (more than twice the amount raised from venture capitalists). All regressions are estimated with two-stage least squares. 


\begin{tabular}{lccc}
\hline \hline & $\begin{array}{c}\text { All } \\
(1)\end{array}$ & $\begin{array}{c}\text { IT only } \\
(2) \\
\text { Firm success }\end{array}$ & $\begin{array}{c}\text { Life Science } \\
(3)\end{array}$ \\
\hline Mean examiner leniency & 0.010 & 0.004 & $0.036^{* *}$ \\
(normalized) & $(0.008)$ & $(0.009)$ & $(0.018)$ \\
\hline Observations & 2191 & 1660 & 531 \\
Sector by 1st round year FE & Yes & Yes & Yes \\
Nr of applications FE & Yes & Yes & Yes \\
Mean of dependent variable & 0.19 & 0.16 & 0.29 \\
R2 & 0.08 & 0.06 & 0.11 \\
\hline
\end{tabular}

Notes: Robust standard errors in parentheses $* p<0.1,{ }^{* *} p<0.05,{ }^{* * *} p<0.01$. These reduced form regressions regress firm success directly on the leniency instrument. Firm success is defined as having an IPO or being acquired at a high price (more than twice the amount raised from venture capitalists. Estimation is by ordinary least squares.. 


\section{A Appendix: life science results with alternative mea- sures of success}

In this appendix, I take a more detailed look at the Life Science subsample with slightly different outcome variables (see table 8). First, I distinguish between IPO and high acquisitions (column 1 and 2). The coefficients for patents are positive (though not significant) in both regressions. Second, I investigate the sensitivity of the firm success to different definitions of high acquisitions (column 3 and 4). The results are qualitatively very similar across different value thresholds (acquisition price above $150 \%$ of venture capital raised, above $200 \%$ of venture capital raised and above $250 \%$ of venture capital raised).

[Insert table 8 about here]

Table 8: Robustness checks for Life Science subsample

\begin{tabular}{lcccc}
\hline \hline & $(1)$ & $(2)$ & $(3)$ & $(4)$ \\
& Had IPO & High Acquisition & Success $(150)$ & Success $(250)$ \\
\hline Patents & 0.076 & 0.073 & $0.145^{*}$ & $0.141^{*}$ \\
(instrumented) & $(0.060)$ & $(0.050)$ & $(0.075)$ & $(0.074)$ \\
\hline Observations & 531 & 531 & 531 & 531 \\
Sector by 1st round year FE & Yes & Yes & Yes & Yes \\
Nr of applications FE & Yes & Yes & Yes & Yes \\
Mean of dependent variable & 0.16 & 0.13 & 0.30 & 0.28 \\
R2 & 0.10 & 0.04 & 0.04 & 0.06 \\
\hline \hline
\end{tabular}

Notes: Robust standard errors in parentheses ${ }^{*} p<0.1,{ }^{* *} p<0.05,{ }^{* * *} p<0.01$. These regressions are run on the Medical/Life science subsample. Column 1 and 2 split firm success in two components - IPO or acquisition at a high price (more than twice the amount raised from the venture capitalists). Column 3 and 4 redefine firm success to be having an IPO or being acquired for more than $150 \%$ and more than $250 \%$ (respectively) of the amount raised from venture capitalists. All regressions are estimated with two-stage least squares. 


\section{Working Paper Series}

ISSN 1211-3298

Registration No. (Ministry of Culture): E 19443

Individual researchers, as well as the on-line and printed versions of the CERGE-EI Working Papers (including their dissemination) were supported from institutional support RVO 67985998 from Economics Institute of the ASCR, v. v. i.

Specific research support and/or other grants the researchers/publications benefited from are acknowledged at the beginning of the Paper.

(c) Patrick Gaulé, 2015

All rights reserved. No part of this publication may be reproduced, stored in a retrieval system or transmitted in any form or by any means, electronic, mechanical or photocopying, recording, or otherwise without the prior permission of the publisher.

Published by

Charles University in Prague, Center for Economic Research and Graduate Education (CERGE) and

Economics Institute of the ASCR, v. v. i. (EI)

CERGE-El, Politických vězňů 7, 11121 Prague 1, tel.: +420 224005 153, Czech Republic.

Printed by CERGE-EI, Prague

Subscription: CERGE-EI homepage: http://www.cerge-ei.cz

Phone: + 420224005153

Email: office@cerge-ei.cz

Web: http://www.cerge-ei.cz

Editor: Marek Kapička

The paper is available online at http://www.cerge-ei.cz/publications/working_papers/.

ISBN 978-80-7343-352-9 (Univerzita Karlova v Praze, Centrum pro ekonomický výzkum a doktorské studium)

ISBN 978-80-7344-344-3 (Národohospodářský ústav AV ČR, v. v. i.) 
CERGE-EI

P.O.BOX 882

Politických vězňů 7

11121 Praha 1

Czech Republic http://www.cerge-ei.cz 